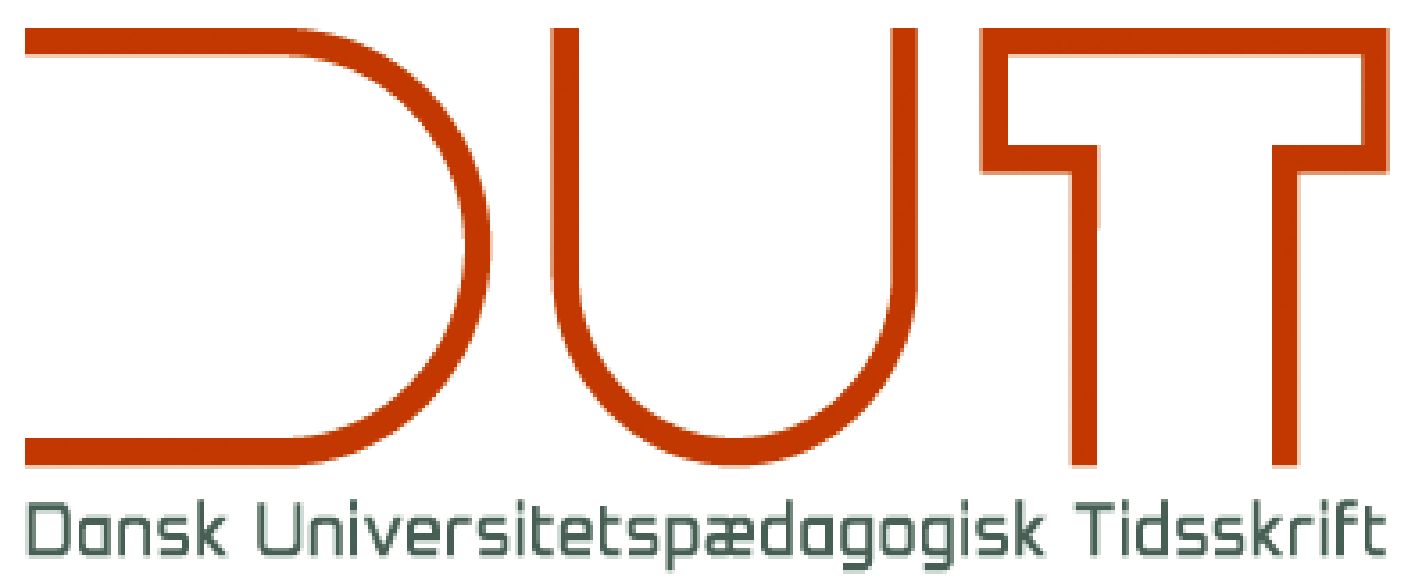

Tema

Autentisk læring

Årgang 15 nr. 29 / 2020

Titel

Forfattere

Sidetal

Can students' attitudes and behaviors be changed by educational interventions?

A comparative case study

Vidar Gynnild, John Sølve Tyssedal

$14-33$

Udgivet af

Dansk Universitetspædagogisk Netværk, DUN

URL

> http://dun-net.dk/

Betingelser for brug af denne artikel

(c) Copyright
Denne artikel er omfattet af ophavsretsloven, og der må citeres fra den. Følgende betingelser skal dog være opfyldt:

- Citatet skal være i overensstemmelse med "god skik“

- Der må kun citeres „i det omfang, som betinges af formålet“

- Ophavsmanden til teksten skal krediteres, og kilden skal angives ift. ovenstående bibliografiske oplysninger.

DUT og artiklens forfatter 


\title{
Can students' attitudes and behaviors be changed by edu- cational interventions?
}

\author{
A comparative case study \\ Vidar Gynnilda,1, John Sølve Tyssedal ${ }^{b}$ \\ a Department of Education and Lifelong Learning, Norwegian University of Science and Technology \\ b Department of Mathematical Sciences, Norwegian University of Science and Technology
}

Videnskabelig artikel, fagfællebedømt

\begin{abstract}
This study examined engineering students' attitudes and behaviors in a first-year Calculus course. Not surprisingly, High School mathematics and physics grades correlated closely with self-reported Calculus grades, and a student survey conducted four years apart demonstrated almost identical attitudes and behaviors despite the introduction of a range of measures aimed to enhance learning. The better the grades, the fairer students deemed it to be, and the less of in-depth learning, the poorer the grades. The higher the ambitions, and the more active and hardworking, the better the grades. Academic success factors included an ability to keep pace with progression, and a commitment to advance learning. The minimal impact of interventions appears as surprising; however, this study brings perspectives to make sense of such data, also capable of producing greater future successes.
\end{abstract}

\section{Introduction}

The importance of Calculus in engineering applications makes it a worthwhile topic for educational research. The purpose of the present study is to explore whether properties of first-year students changed as a result of educational interventions conducted from 2013 through 2015, and a case study methodology was applied to collect data shortly after the end-of-term exams in 2014/2015 and 2018/2019. The estimated workload of Calculus was 7.5 credits, equaling $1 / 4$ of the total in the first semester of study, and enrollments exceeded 1,500 annually. Learning outcomes were as follows:

"The student understands and is able to recognize and apply concepts, results, and methods from single-variable analysis which deals with limits, continuity, differentiation, integration, convergence of sequences and series, Taylor polynomials, and Taylor series. The student understands and is able to apply basic numerical methods for solution of nonlinear equations, differential equations, and integration, and is aware of the possibilities and limitations that lie in the use of mathematical software."

(https://www.ntnu.edu/studies/courses/TMA4100\#tab=omEmnet, accessed June 8, 2020).

Calculus is one of four mandatory courses in the first semester of the first year. By experience, transitions from High School to University are known to be tricky even for talented students, leading to dropouts and grades at the lower end of the scale. The situation in Calculus was no different. By the turn of the century, failure rates peaked, prompting the department to

${ }^{1}$ Contact: vidar.gynnild@ntnu.no 
intervene. Minor curricular changes took place over the years; however, more systematically so from 2013 through 2015. As an evaluation study the present article reports on correlations before and after interventions occurred.

An "attitude" is contextualized as ability and willingness to learn. Our premise is that attitudes represent learned behavior and as such can be changed by adequate educational interventions. The term "study behavior" is used as a superordinate concept including both study habits and attitudes to study. The authors hypothesize that students, irrespective of their level of ability, may engage in study behaviors that may either enhance or detract from academic achievement. The purpose of the present study is not to replicate studies on "approaches to learning" based on validated survey instruments. Rather, we are concerned with issues of change and conceptualizations of causality.

The following research questions guided the design of this study: Did patterns of attitudes and study behaviors change over time in each of the two cases? (1); what, if anything, is surprising about these patterns? (2); and, how can they be explained and possibly changed? (3). The authors analyzed and synthesized differences and similarities between two cohorts of students. Descriptive statistics as seen in graphical plots are used to visualize characteristic patterns across the two cases.

\section{Theoretical Background}

Calculus is an entry point to continued university studies; however, several students struggle to get passed this academic "hurdle" successfully. Researchers have reported on rote, manipulative learning, and studies report on a wide spectrum of concepts causing problems (White \& Mitchelmore, 1996). Learning is often characterized by memorization of symbols and procedures rather than construction of meaning, and calculus students often lack abilities to reason from basic principles (Heid, 1988). Consequently, Heid (1988) argued in favor of concepts as the primary focus after which she believed skill development would follow suit. Some evidence to confirm this hypothesis was found by Heid (1988), while also assuming that the introduction of computing devices would be helpful tools for the refocusing of mathematics curricula with an emphasis on conceptual learning.

Furthermore, foundational ideas in differential calculus have proven difficult to learn by using traditional instructional methods (Sofronas et al., 2015). Typical misconceptions include confusing a function with a formula and not accepting other representations: "In addition, though students primarily regard a function as 'something you plug numbers into,' they still manage to consider it static, making it difficult to understand concepts such as limits" (Pyzdrowski et al., 2013, p. 513). First-year calculus has been characterized as a "... filter, discouraging all but the very strongest students from pursuing a career in science and engineering" (Bressoud, Carlson, Mesa, \& Rasmussen, 2013), acting almost like a stumbling block for some students (Pyzdrowski et al., 2013).

A different strand of research has been preoccupied with retention and pass rates along with issues of conceptual content (Bressoud, Ghedamsi, Martinez-Luaces, \& Törner, 2016; Jaworski, Mali, \& Petropoulou, 2017; Reinholz, 2015). Furthermore, motivation, enjoyment, and confidence have been explored, and several studies refer to relationships between beliefs, motivation and achievement (Harrison \& Risler, 2015; Trigwell, Prosser, \& Waterhouse, 1999). Confidence has been identified as a significant predictor of achievement, with the self-rated overall academic achievement as the most significant predictor (House, 1995). Years ago, The National 
Research Council in the US encouraged educators to incorporate affective along with cognitive factors in teaching (Ma \& Kishor, 1997).

A range of teaching and learning methods have been explored. Examples include inquirybased learning (Hayward, Kogan, \& Laursen, 2016), flipped classrooms (Cronhjort, Filipsson, \& Weurlander, 2017; Maciejewski, 2016) and peer-assisted reflection (Reinholz, 2015). A different strand of research has been preoccupied with characteristics of students. While House (1995) identified attitudes as a significant predictor of achievement, another study concluded that High School point average correlated with calculus achievements (Pyzdrowski et al., 2013). Academically successful students have been characterized by resilience Johnston-Wilder \& Lee, 2010), while low achievers more often resort to defensive strategies (Wheland, Konet, \& Butler, 2003). Surprisingly, research universities have been found to do the worst job in maintaining confidence and interest: Students "... show the greatest losses, even though [...] they are the best prepared" (Bressoud et al., 2013, p. 695).

Similar observations were reported by Snyder fifty years ago in his seminal book on college learning (Snyder, 1971). Even honest efforts to enrich curricula often failed due to the impacts of tacit knowledge held by students. Snyder explained his observation by the existence of two curricula, the "open" and the "hidden". He theorized that the latter emerged due to reactions on key dimensions such as workload, progression and tasks encountered at final exams. Some cope by adopting instrumental approaches different from those recommended and expected. Students may not even be aware of the disjunction between the two curricula; however, the end result of poor learning is of concern to faculty and employers alike. Snyder's discovery of the two curricula alerts us that teaching and study programs may impact learning in ways that are at odds with intentions.

\section{Data and Method}

As a comparative case study, this article reports empirical data gathered in the same course at different points in time, with a view to issues of causality to inform future interventions. For the current analysis we used self-reported mathematics and physics grades from High School and Calculus grades along with survey data collected digitally and anonymously in January of 2015 and 2019. The authors were granted access to the distribution of Calculus grades for the entire cohorts to examine representativeness of the samples.

556 candidates completed the survey in 2015 versus 201 in 2019, and grades were correlated with item responses on a 1-9-point Likert scale. Comparative case studies often incorporate both qualitative and quantitative data; however, this study draws exclusively on quantifiable survey data and self-reported grades. The synthesis across cases extends beyond the reporting of differences and similarities as we wish to use data to support or refute claims of learning, as we believe such evidence would be valuable in tailoring future interventions. If similar patterns reoccur despite interventions, what might explain such patterns, and how can they possibly be changed?

Figure 1 and Figure 2 compare grades reported in surveys with grade distributions of the entire cohort of Calculus candidates in 2014/2015 and 2018/2019, respectively. 


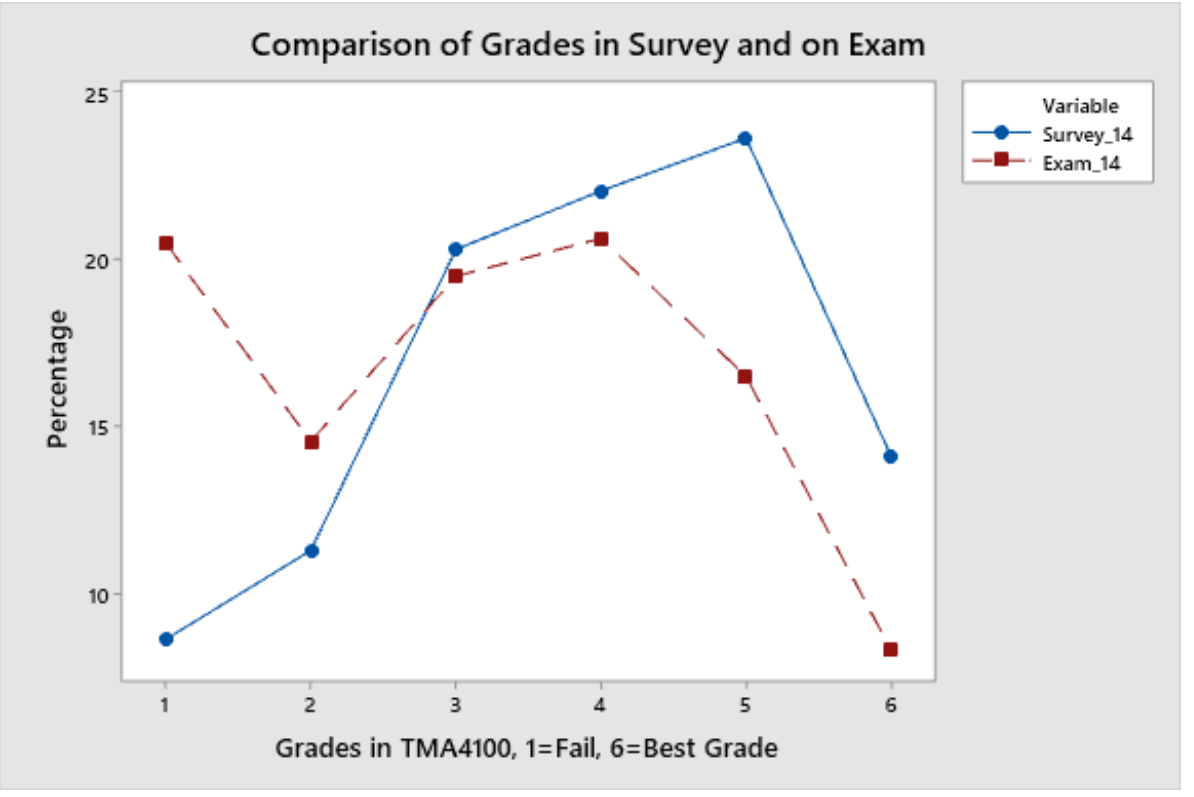

Figure 1: Comparison of grades as reported in survey (blue) compared with total grade distributions in 2014/2015

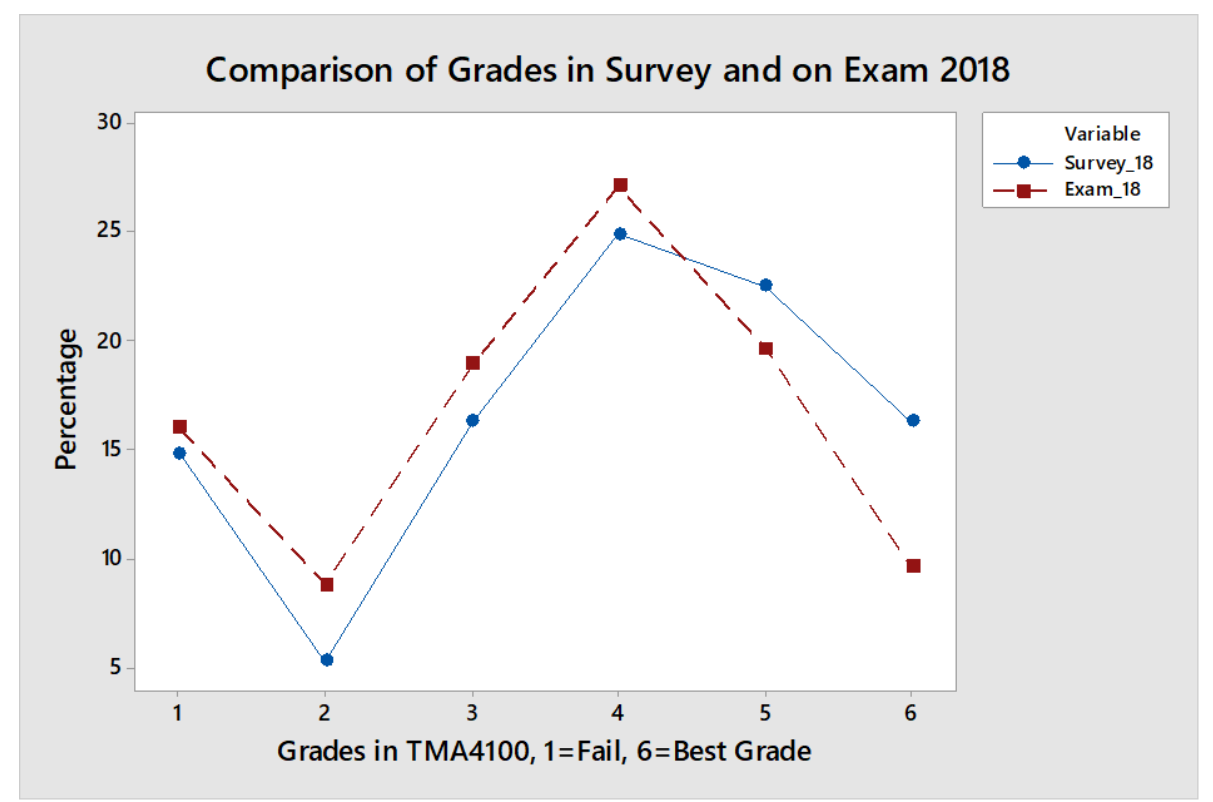

Figure 2: Comparison of grades as reported in survey (blue) compared with total grade distributions in 2018/2019

Taking the relative frequencies for the grades in the entire cohorts as the hypothesized distributions, a chi-square goodness of fit test will lead to rejection for both samples using a $5 \%$ level of significance. This is due to students with the best grades being overrepresented and fortunately so in both samples. The discrepancy may be a little larger in 2014 than in 2018. This will not necessarily affect the profile plots presented, since these are based on averages and not on counts, but it may have some impact on the chi-square tests on changes in attitudes and behavior, though it is hard to explain how this should render the few potential differences that will be pointed out. 


\section{Educational Interventions}

Table 1 features educational interventions including timing and purpose. Items demonstrate a commitment to constructivist learning theory and "active" learning by providing a range of interventions for greater flexibility to meet the needs of students. The traditional one-way lecturing style was replaced by a combination of overview lectures and interactive lectures. Overview lectures aimed at covering key topics and theory and took place in classes of up to 500, while interactive classes were organized in smaller groups in the range of 100-200 students. Weekly exercises were accessed through a digital platform called Maple TA in 2013, enabling the use of different sets of problems and responses in terms of right or wrong answers. Most Maple TA exercises required only imitative reasoning, while creative reasoning took place in interactive lectures (Rønning, Buan, Langaas, \& Thaule, 2017). Alongside structural changes, learning materials such as online thematic pages and videos were added (Langaas, Buan, Skauvold, \& Thaule, 2017).

In retrospect, students expressed satisfaction with the new course design, particularly the opportunity to work collaboratively with instructors (Thaule, Buan, Rønning, \& Langaas, 2017).

However, universities are complex systems, and outcomes are not easily foreseen. This study aims to move beyond statements of satisfaction to real impacts on attitudes and behaviors.

\begin{tabular}{|c|c|c|c|}
\hline & Description & Purpose & Start \\
\hline 1. & $\begin{array}{l}\text { Tutorials of weekly exercises in } \\
\text { groups of } 5 \text { pprox.. } 30 \text { students with } \\
\text { one learning assistant replaced with } \\
\text { coaching in larger rooms with sev- } \\
\text { eral learning assistants and PhD can- } \\
\text { didate(s) present. Open every day } \\
\text { from 12-18 (Friday to 16). }\end{array}$ & $\begin{array}{l}\text { - Make the access to tutoring easier } \\
\text { and more flexible for students } \\
\text { (they can apply for guidance when } \\
\text { they want during the opening } \\
\text { hours). } \\
\text { - Increase the professional compe- } \\
\text { tence of the supervisory staff (by } \\
\text { also having PhDs attending). } \\
\text { - Increase flexibility by multiple } \\
\text { coaches. } \\
\text { Give students the opportunity to } \\
\text { collaborate and seek guidance as } \\
\text { needed. }\end{array}$ & $\begin{array}{l}\text { Fall } \\
\text { of } \\
2013\end{array}$ \\
\hline 2. & $\begin{array}{l}\text { Introduction of weekly digital exer- } \\
\text { cises (system Maple T.A.) with an au- } \\
\text { tomated response system in replace- } \\
\text { ment of weekly submissions super- } \\
\text { vised by learning assistants. }\end{array}$ & $\begin{array}{l}\text { Move human resources from cor- } \\
\text { rection to guidance of exercises. } \\
\text { Individualize exercises (Maple T.A. } \\
\text { generates, to some extent, differ- } \\
\text { ent tasks for each student). }\end{array}$ & $\begin{array}{l}\text { Fall } \\
\text { of } \\
2013\end{array}$ \\
\hline 3. & $\begin{array}{l}\text { Introducing project assignments for } \\
\text { presentation in groups. Requirement } \\
\text { of at least one presentation by each } \\
\text { student and attendance at a certain } \\
\text { number of peer presentations. }\end{array}$ & $\begin{array}{l}\text { Increase learning outcomes by } \\
\text { having to present and explain as- } \\
\text { signments to peers. }\end{array}$ & $\begin{array}{l}\text { Fall } \\
\text { of } \\
2013\end{array}$ \\
\hline 4. & $\begin{array}{l}\text { Introducing digital learning re- } \\
\text { sources: Videos (short, thematic }\end{array}$ & $\begin{array}{l}\text { - Increase flexibility in terms of } \\
\text { methods. }\end{array}$ & $\begin{array}{l}\text { Fall } \\
\text { of } \\
2013\end{array}$ \\
\hline
\end{tabular}




\begin{tabular}{|c|c|c|c|}
\hline & $\begin{array}{l}\text { videos and recording of lectures), } \\
\text { pencasts and theme pages online. }\end{array}$ & $\begin{array}{l}\text { - Improve access to learning re- } \\
\text { sources. }\end{array}$ & \\
\hline 5. & $\begin{array}{l}\text { Reintroduction of submissions (4 per } \\
\text { semester), in addition to Maple T.A. } \\
\text { exercises. Project assignments for } \\
\text { presentation omitted. Effort to im- } \\
\text { prove the quality of the Maple T.A. }\end{array}$ & $\begin{array}{l}\text { - Students wanted more detailed } \\
\text { feedback on written work than } \\
\text { was feasible with Maple T.A. } \\
\text { Presentation of project assign- } \\
\text { ments was assessed by students; } \\
\text { however, yielded poor learning } \\
\text { (coaches and learning assistants } \\
\text { were probably not adequately } \\
\text { qualified for the job). }\end{array}$ & $\begin{array}{l}\text { Fall } \\
\text { of } \\
2014\end{array}$ \\
\hline 6. & Introduction of interactive lectures. & $\begin{array}{l}\text { - Increase the possibility of interac- } \\
\text { tion between students and be- } \\
\text { tween students and teachers. }\end{array}$ & $\begin{array}{l}\text { Fall } \\
\text { of } \\
2015\end{array}$ \\
\hline 7. & $\begin{array}{l}\text { Introducing "counting exercises": All } \\
\text { approved Maple T.A. exercises and } \\
\text { all written submissions count } 20 \% \\
\text { towards the final grade. Final written } \\
\text { exam counts } 80 \% \text { but must be } \\
\text { passed in order to achieve an overall } \\
\text { passing grade in the course. }\end{array}$ & $\begin{array}{l}\text { - Increase students' motivation to } \\
\text { work steadily throughout the se- } \\
\text { mester. }\end{array}$ & $\begin{array}{l}\text { Fall } \\
\text { of } \\
2015\end{array}$ \\
\hline
\end{tabular}

Table 1: List of interventions in Calculus from 2013 through $2015^{2}$

\section{Data and Analysis}

Profile plots are used for graphical comparisons of the 2014/2015 and 2018/2019 cohorts.

The profiles are plots of averages for each grade. In addition to averages, estimated standard deviations may be computed and from these estimated standard deviations for comparing differences in means may be derived. Comparing the differences in averages to twice their corresponding estimated standard deviation for a given grade may indicate whether two profiles means are different or not. It turned out that as a rough approximation, these estimated standard deviations could be divided into two groups, one for the two lowest grades and one for the four highest ones. Estimated standard deviation for the differences in means for the variables in the plots are given in Table 2. However, to conclude that two profiles are different, all grades need to be taken into consideration.

Chi-square tests may be used to test for homogeneity in the cohorts, and the different points on the Likert scale were taken as category levels. Assuming levels of agreement to questionnaire items mean the same in 2014/2015 and 2018/2019, changes in attitudes and behaviors from one year to the other are examined. By statistically significant we mean significant on a $5 \%$ level.

\footnotetext{
${ }^{2}$ Provided by Professor Frode Rönning, NTNU, who was heading the interventions.
} 


\begin{tabular}{|l|c|c|}
\hline Variable & $\begin{array}{l}\text { Standard deviations } \\
\text { for differences for the } \\
\text { two lowest grades }\end{array}$ & $\begin{array}{l}\text { Standard deviations for dif- } \\
\text { ferences for the four high- } \\
\text { est grades }\end{array}$ \\
\hline R2 to F2 2018 & 0.22 & 0.14 \\
\hline Fair & 0.45 & 0.27 \\
\hline Valid & 0.51 & 0.30 \\
\hline Own effort & 0.43 & 0.35 \\
\hline No in-depth & 0.55 & 0.40 \\
\hline Ambition to pass & 0.57 & 0.30 \\
\hline Being passive & 0.54 & 0.36 \\
\hline Struggling making sense & 0.59 & 0.28 \\
\hline Intent of understanding & 0.53 & 0.42 \\
\hline Managed to keep pace & 0.50 & 0.44 \\
\hline Ambition accepted exercise & 0.66 & 0.38 \\
\hline
\end{tabular}

Table 2: Estimated standard deviations for comparing differences in means

In Figure 3, Mathematics and Physics grades from High School are compared with self-reported Calculus grades in 2014 and 2018. Findings are that those who succeeded in High School did so also in Calculus. A Chi-square test does not confirm differences in High School grade distributions in 2014 and 2018 while Calculus grades differ in the samples as the 2018 sample features more F's and fewer E's compared with 2014, a situation caused by a new grading regime introduced in 2015.

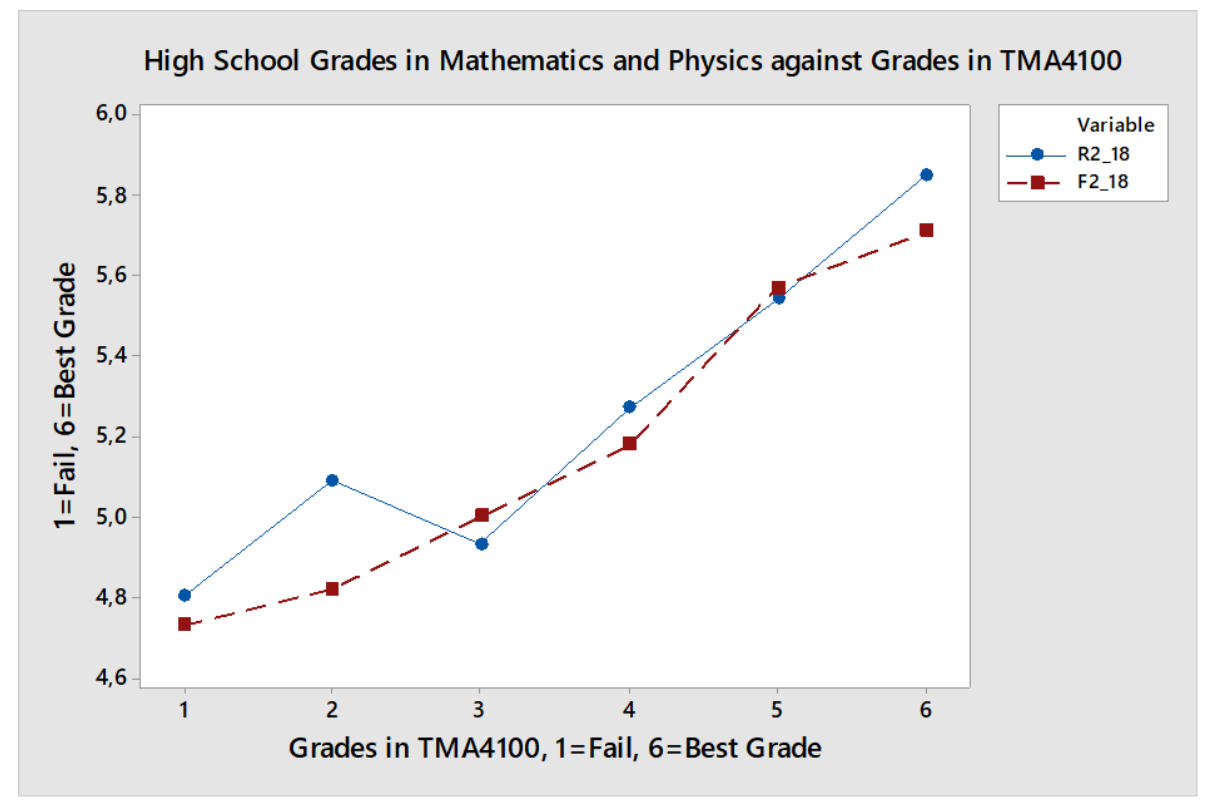

Figure 3: High School Mathematics (R2 Blue line) and Physics (F2 Red line) against Calculus grades 
Plots in Figure 4 and Figure 5 feature relationships between Calculus grades and opinions on fairness and validity, as gauged through the following items: "To what extent do you perceive your Calculus grade as fair in view of your own performance?" (Figure 4) and, "To what extent does the Calculus grade give an accurate picture of the knowledge and skills you think you possess?" (Figure 5). Responding to these items implies the application of subjective criteria; however, we cannot be sure they were identical on both occasions. Nonetheless, Figures 4 and 5 exhibit similar trends; as grades improve, so do the perceived fairness and accuracy, and vice versa. However, a Chi-square test confirms that students consider assigned grades in 2018 fairer compared with the cohort of 2014.

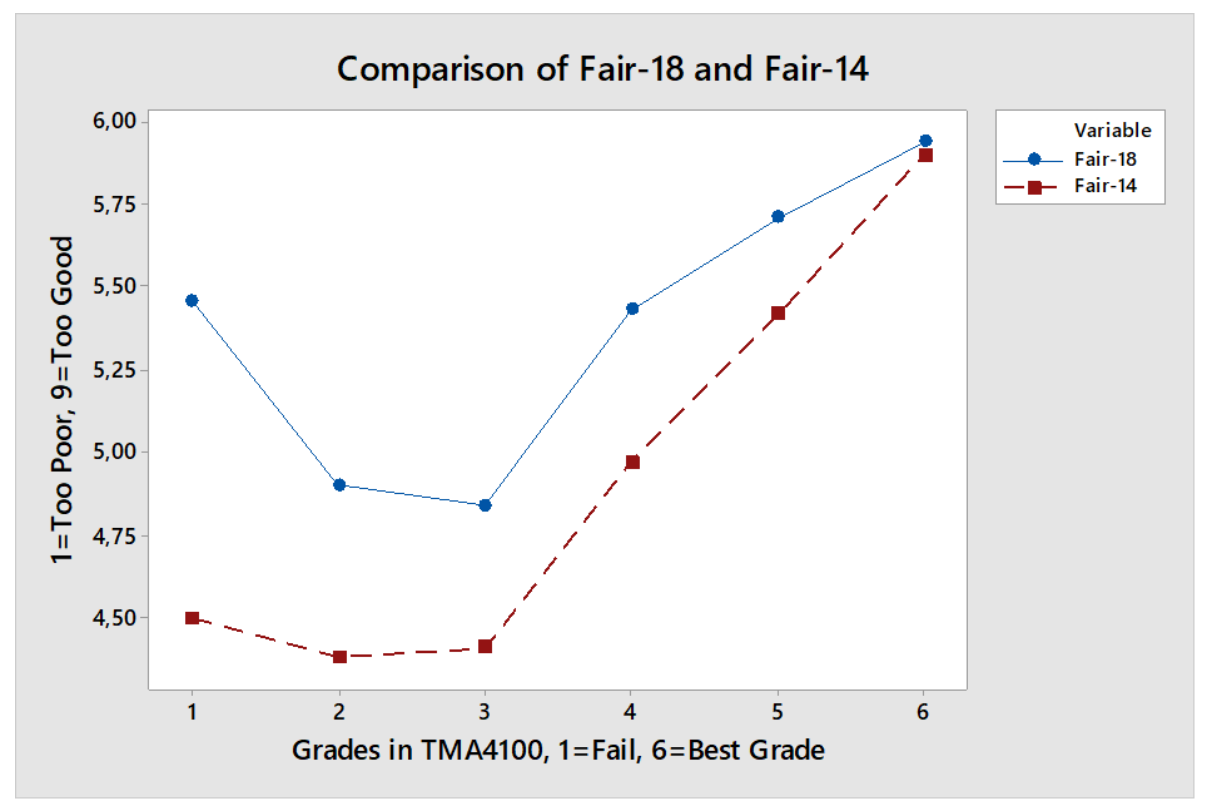

Figure 4: Students' perceptions of the degree of fair grading in Calculus in 2014/2015 (red line) and 2018/2019 (blue line)

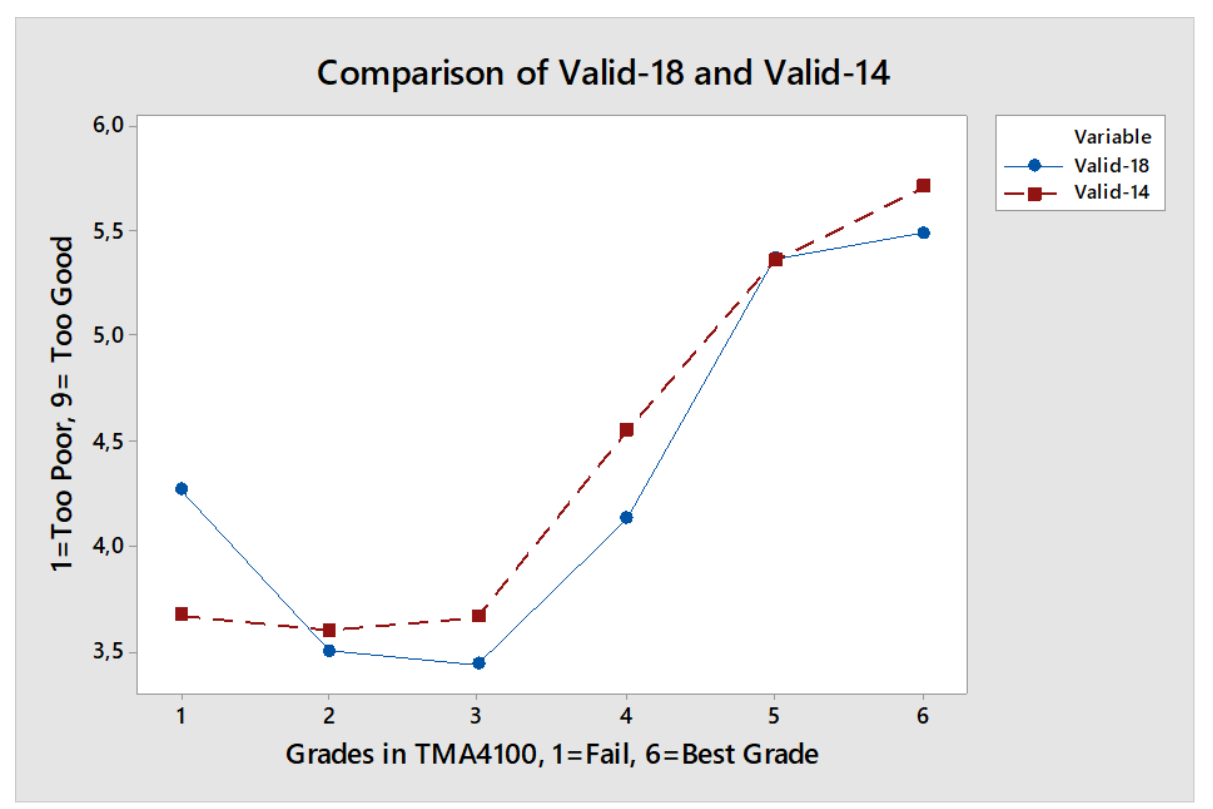

Figure 5: Comparison of students' opinions on the validity of grading in 2014/2015 (red line) and 2018/2019 (blue line) 
Figure 6 and Figure 7 portray responses to the following items: "My priority was solely to pass, and I did not care about my grade level" (Figure 6), and, "To what extent do you agree with the following statement: When I was doing Calculus, I was intent on understanding concepts and underlying principles in the subject matter" (Figure 7).

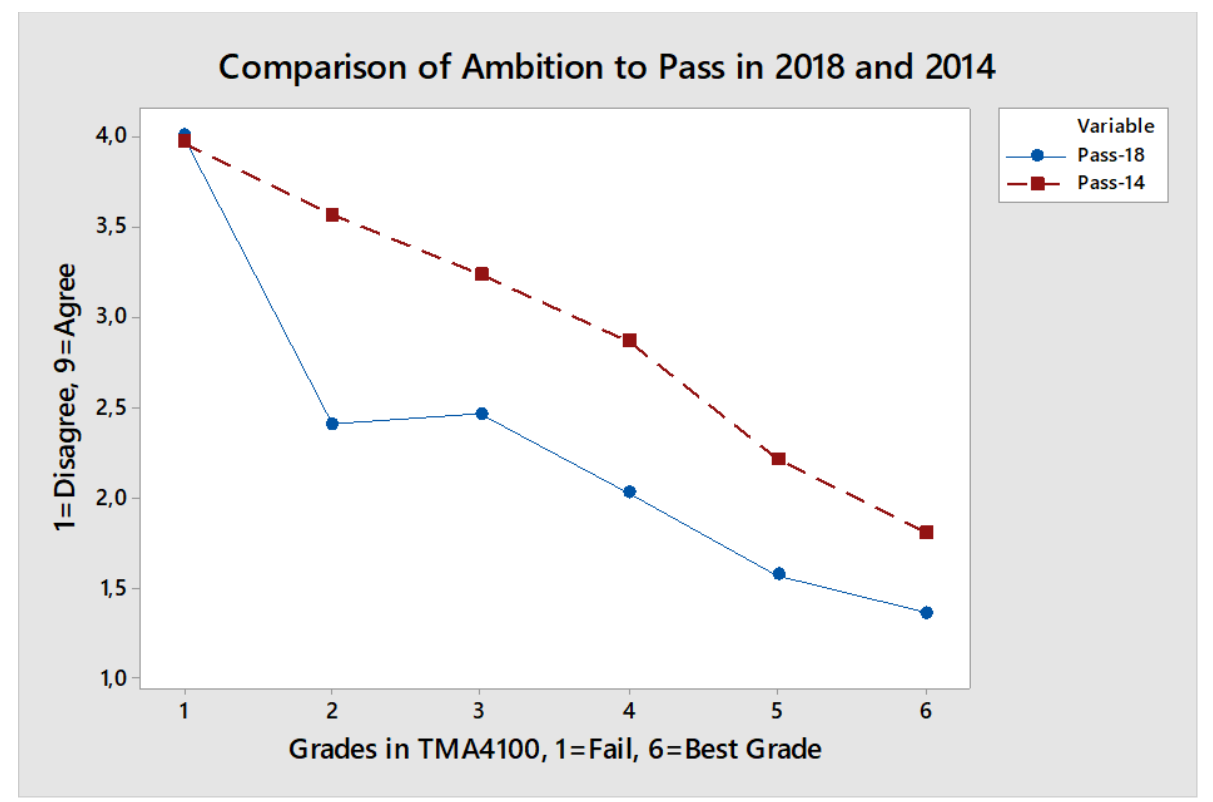

Figure 6: Comparison of ambition to pass in 2014/2015 (red line) and 2018/2019 (blue line)

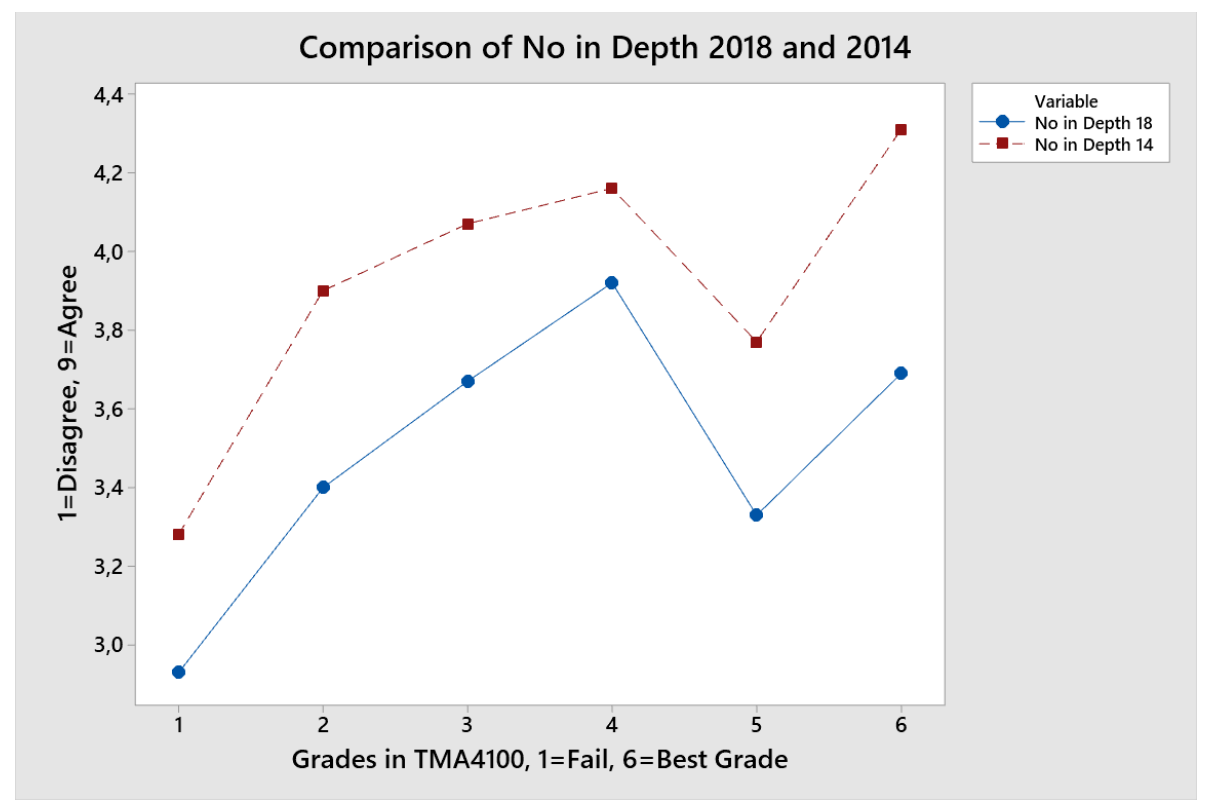

Figure 7: Comparison of intention to understand concepts and underlying principles in Calculus in 2014/2015 (red line) and 2018/2019 (blue line)

Inclinations to simply pass the course correlate with poor grades, and, as the focus on deep learning increased, so did assigned grades. Furthermore, students were more prone to pursue deep learning strategies in 2018 compared with 2014. A Chi-square test confirms differences in intentions of just passing the course in 2014 and 2018. Students agreed to a lesser extent that their ambition was solely to pass in 2018 compared with 2014; however, the difference is not statistically significant. 
Figures 8 and 9 present responses to the following items: "I was relatively passive and was afraid of failing Calculus" (Figure 8), and, "I was committed to memorizing methods and techniques without processing or making connections to key concepts in the course, and I experienced significant challenges in trying to figure out why the various methods in calculus work" (Figure 9). As seen in Figure 8 and 9, trends in 2014/2015 and 2018/2019 are similar; however, on a separate comparison on a survey item addressing the use of exercises, a Chisquare test indicates that students agree to a lesser extent that their ambition was exclusively to get exercises approved in 2018 compared with 2014.

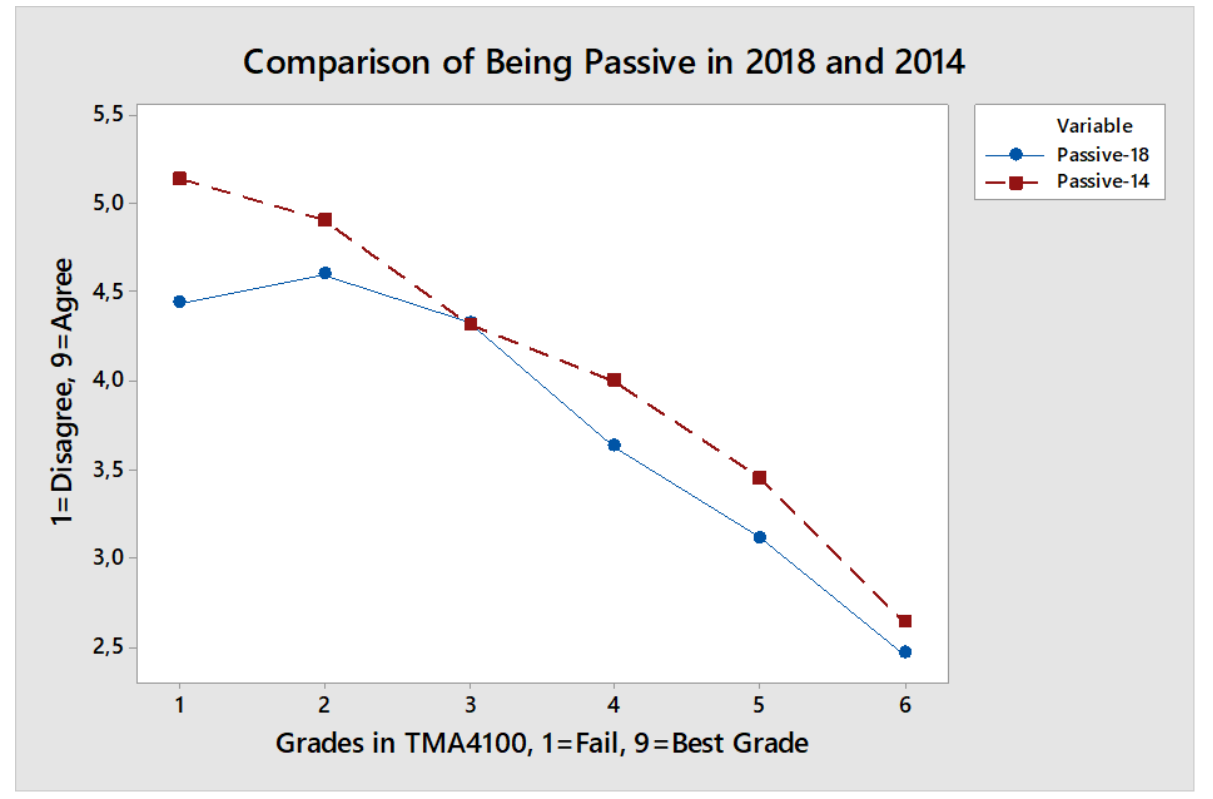

Figure 8: Comparison of being passive and assigned grades in Calculus in 2014/2015 (red line) and 2018/2019 (blue line)

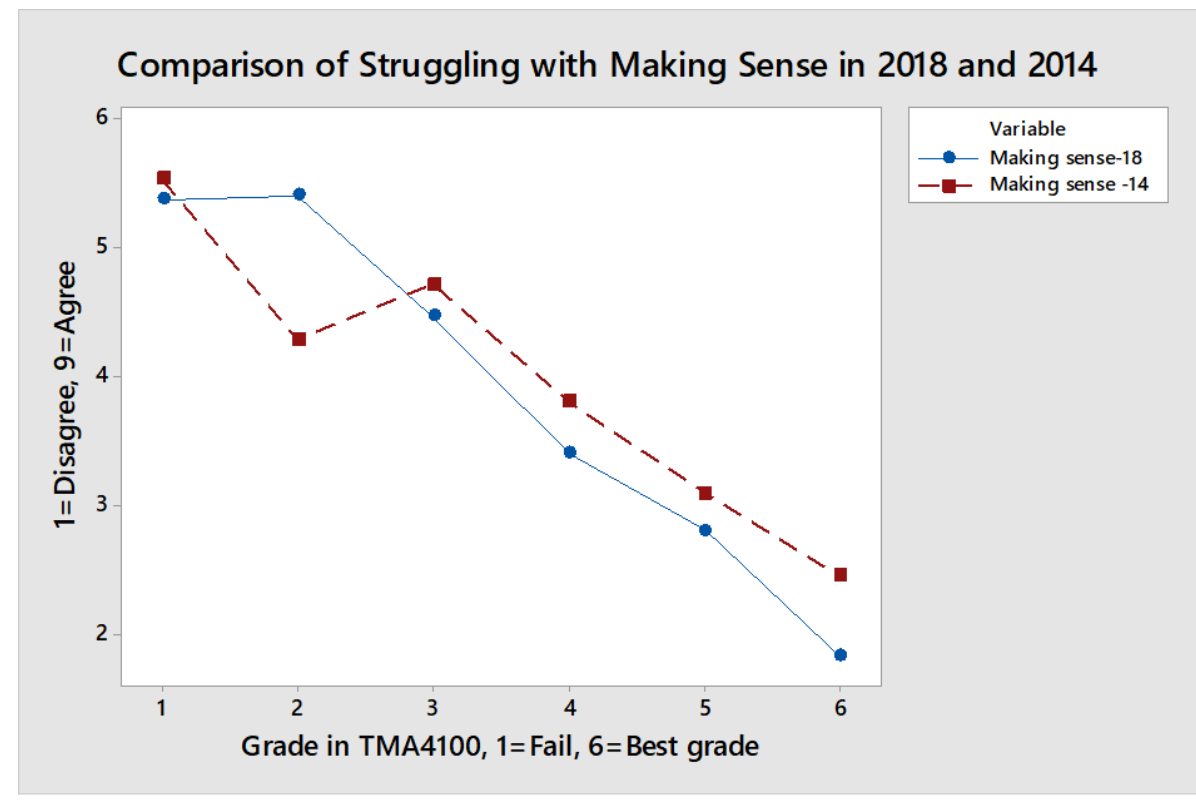

Figure 9: Comparison of struggling with making sense and assigned grades in 2014/2015 (red line) and 2018/2019 (blue line) 
Figures 10 and 11 illustrate students' responses to the following items: "In Calculus, I was committed to making sense of the concepts and underlying principles in the course, and to identifying interconnections in ways that would make sense to me" (Figure 10), and, "I was able to keep pace with the progression throughout the semester" (Figure 11). Committing to making sense appears to be fruitful for academic attainment, as is the ability to keep pace with progression. The more students commit themselves to making sense of Calculus content, the more effort they invest in learning activities, and, the more they manage to keep pace with progression, the better the assigned grades.

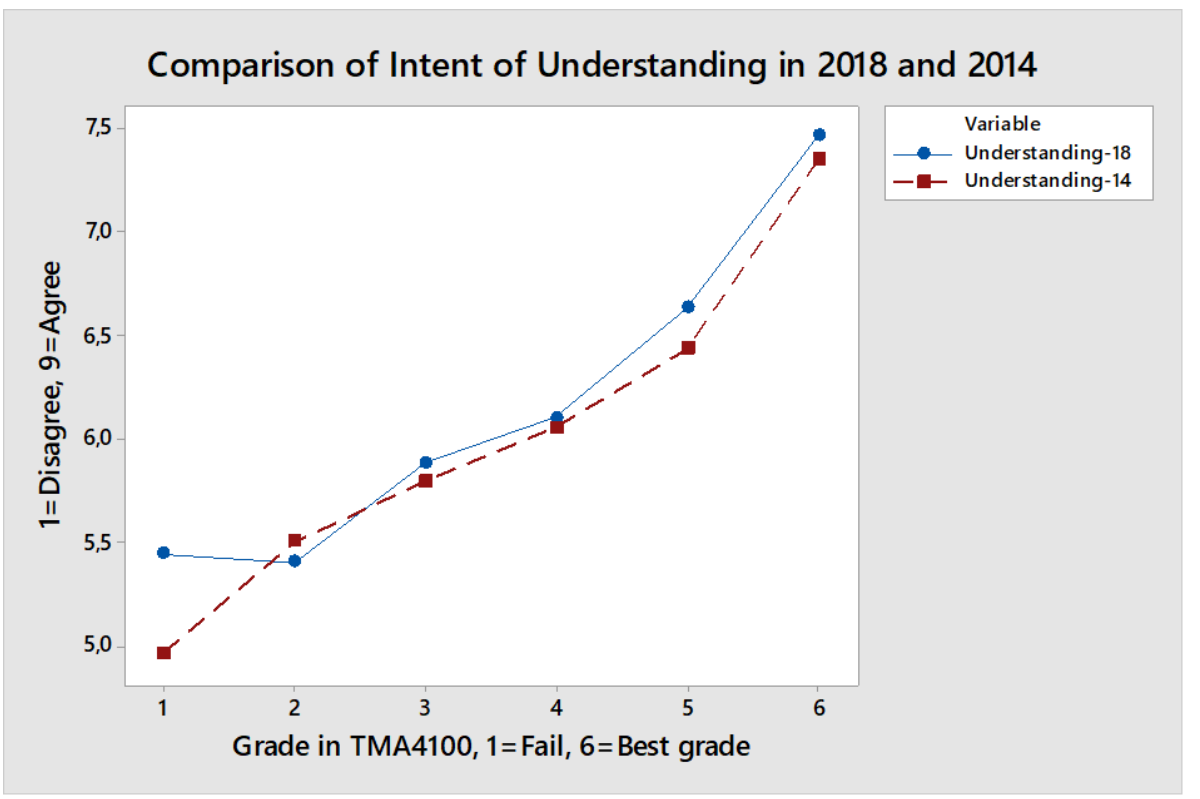

Figure 10: Comparison of intent on understanding and assigned grades in 2014/2015 (red line) and 2018/2019 (blue line)

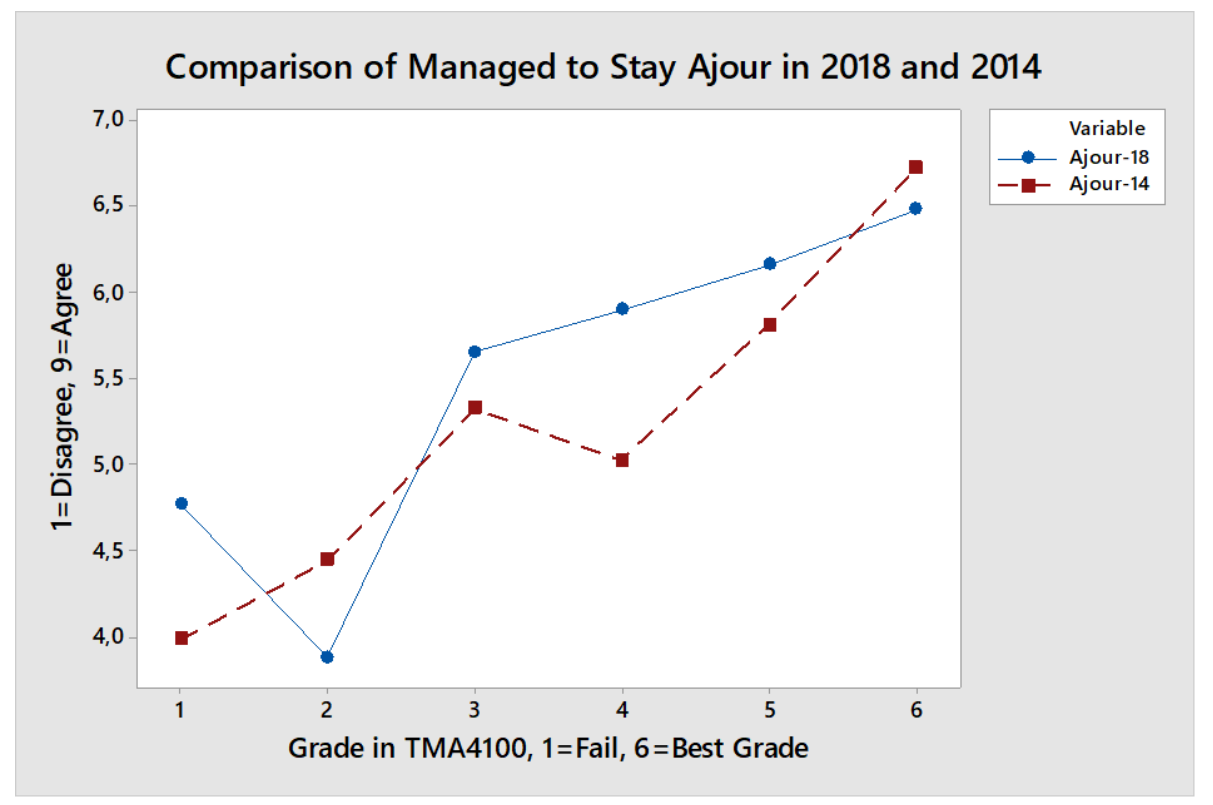

Figure 11: Comparison of managing to keep pace with progression in 2014/2015 (red line) and 2018/2019 (blue line) 
Learning requires time and maturation while just getting a pass could be obtained by memorization strategies. The authors explored this by asking students to respond to the following statement: "My intention during the tutorials was only to have the exercises approved and not to achieve deep learning". As seen in Figure 12, those who disagreed received the best grades, while those who agreed received the poorest grades. Academically successful students in 2018/2019 agreed to a lesser extent compared with their peers in 2014/2015. A Chi-square test also confirms differences in ambitions to only get exercises accepted in 2014 and 2018. This indicates a change in that those aiming for the better grades were more committed and resilient compared with their less academically ambitious peers.

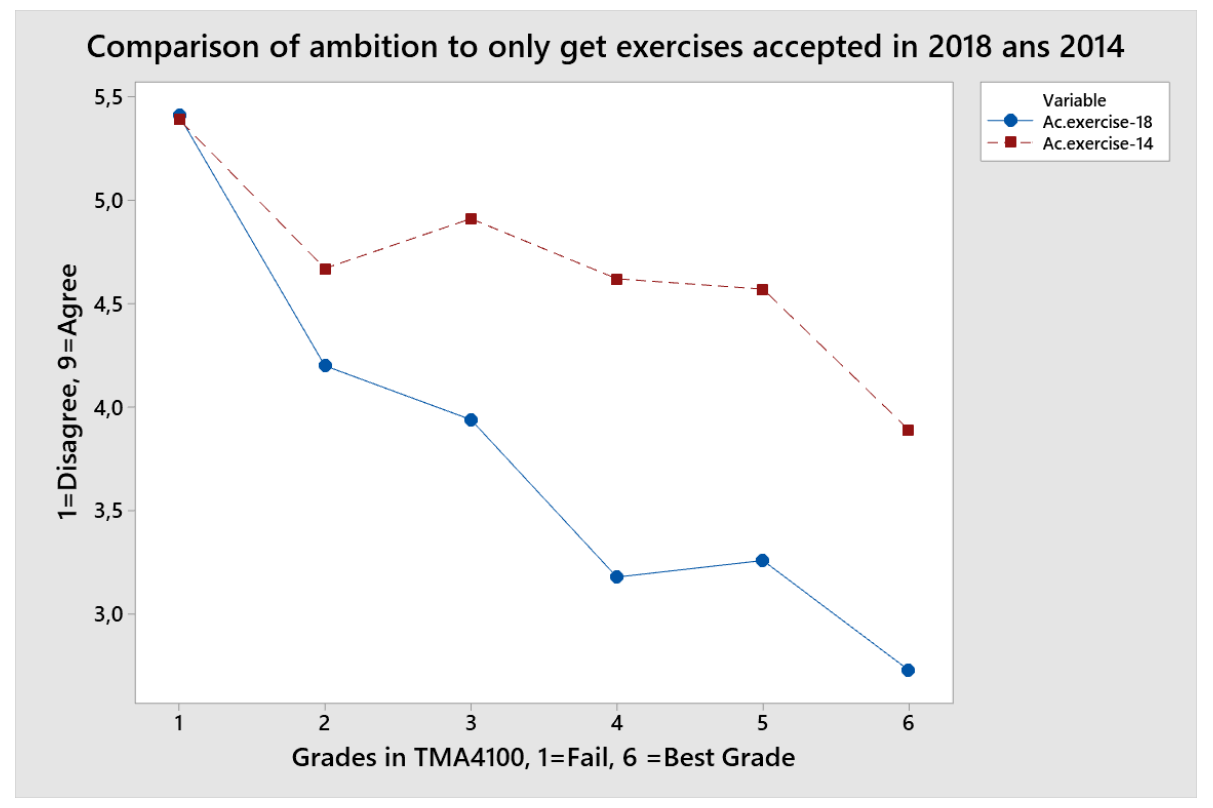

Figure 12: Comparison of ambition to only get the exercises approved in 2014/2015 (red line) and 2018/2019 (blue line)

Figure 13 features responses to this item: "How do you assess your own effort in Calculus?"

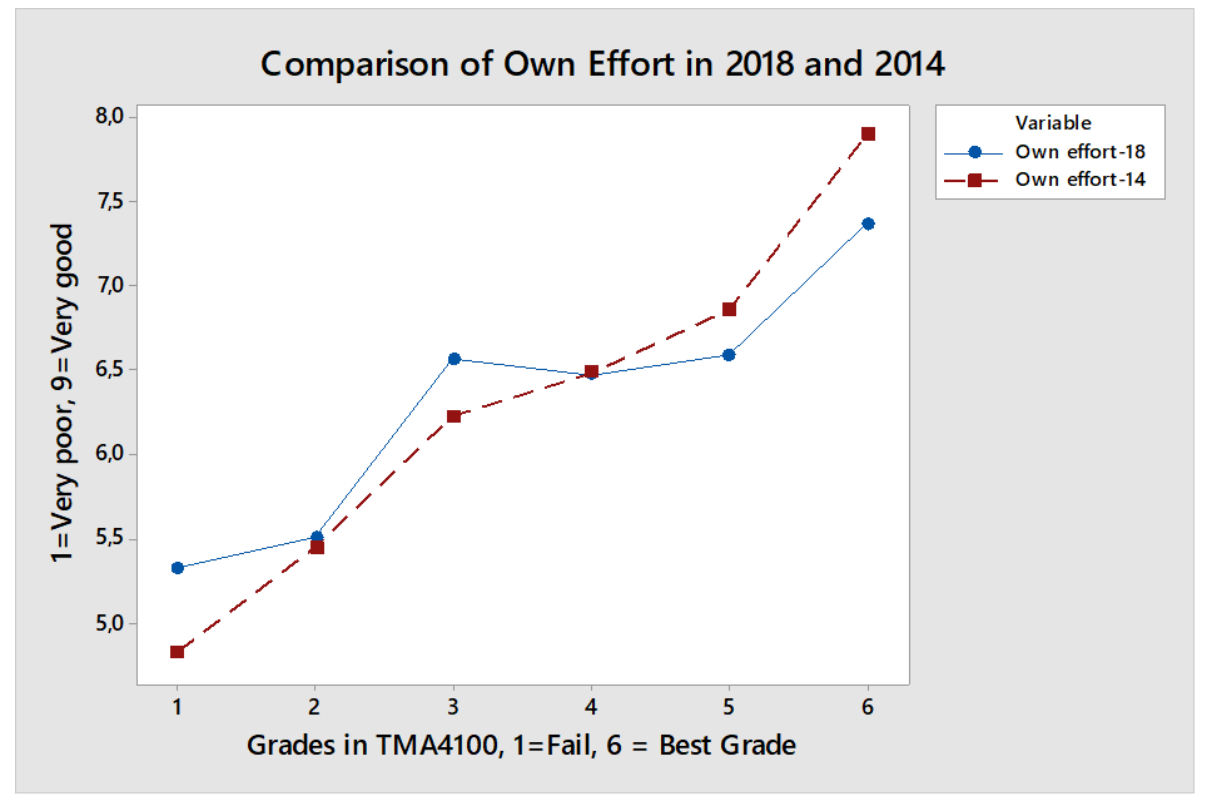

Figure 13: Comparison of own effort in 2014/2015 (red line) and 2018/2019 (blue line) 
Students trying to optimize grades by minimum effort earned the poorest grades, and vice versa. This is well documented elsewhere; "students who are strategic in their orientation tend to wrestle with the formative elements and see them as mini summative assessments" (Frost \& Connolly, 2015, p. 53).

The plots demonstrate striking similarities between $2014 / 2015$ and 2018/2019 with only minor differences observed from one case to the other. This is surprising in consideration of the broad spectrum of educational interventions. It appears as if these failed to enable substantial changes. This observation is contrasted by positive responses reported in satisfaction surveys of teaching; however, such data have little to offer when it comes to evidence of learning processes and outcomes. This echoes with the debate on what count as "evidence" in education, and how this links with practice.

It is a widely held belief that teaching can be improved by observing students' learning, and the construct of "approaches to learning" has dominated educational debates for decades. Inherent in this line of thought is the notion that learning could be impacted by teachers' approaches to teaching (Case, 2015). However, this position has been criticized in recent years since "... a theory with this degree of simplicity cannot possibly account for the complexity of teaching ..." (Case, 2015, p. 627). Consequently, there will be no direct causal link between teaching and learning. Correlations, as seen in this study, do not prove causality but rather raise questions associated with underlying processes. As researchers we are keen to identify causal links to make future interventions more efficacious.

Grounded action (GA) offers practical guidelines to make targeted interventions based on datadriven research: "Actions that are not directly and systematically related to what is relevant in the action scene/context are destined to fail at producing and sustaining the desired change" (Simmons \& Gregory, 2003). To facilitate social change, creating an explanatory theory is the first step ensued by a more practical operational theory. Given the complexity of social systems, the use of GA requires experience and patience, because what appears as the problem may not be the real one. Creating an explanatory theory sets the scene for examination of each of its dimensions to produce a blueprint for action. Any action must earn its way and be supported by data (Simmons \& Gregory, 2003).

By attending to the interventions in Table 1, it appears that most of them are intentional rather than grounded. Only one of seven items links to student feedback and concerns over poor learning (Table 1, item 5). Learning issues are not specified and made explicit and no attempt seems to be made to theorize causal links. A systematic analysis of learning outcomes as seen at exams could have yielded a less comprehensive but more targeted plan of action in which effects would have been easier to trace. Current interventions seem to be based on the notion that students' learning will be improved by ease of access to extra resources, increased flexibility and improved feedback. However, there is no mention of unintended consequences caused by e.g. high workloads and speedy progression.

Social theory is a demanding topic to get to grips with; however, diverse positions are useful to shed light on aspects of reality that might otherwise be hidden. While Grounded Action outlines step-by-step procedures, Critical Realism (CR) offers a philosophical framework of great interest. A key tenet is the divide between what we know (epistemology) and what is real (ontology). Proponents of CR assume reality to be complex and multilayered, and the metaphor of an iceberg has been used to illustrate three different layers of which only one, the empirical level, represents the world around us that can be directly experienced and observed (Archer, 
2010). At the next layer, the actual level, events occur whether observed or not; however, underneath is the layer termed the real level with the properties and structures causing events to occur (Fletcher, 2017). Causal mechanisms can only be identified in the activities they govern, and not independently of them (Fletcher, 2017).

Some would deem CR purely philosophical and of little relevance for studies of higher education; however, similar, if not identical, concerns could be attributed to positivism as well as constructivism. One merit of CR is the openness to include properties of different kinds, such as human feelings and intentions in addition to physical objects. According to Archer (2010), a "property" refers to the "aggregate consequence of prior action" (p. 239), and structures refer to the arrangement of, and relations between properties. CR is concerned with the role of the free will versus determinism, between the role of the individual and the society. A key assumption is that structural conditioning pre-dates actions aimed at transformations, and "... continues to exert a constraint which cannot be assumed to be insignificant in its social consequences" (Archer, 2010, p. 232).

"The initial structural distribution of a property... influences the time taken to eradicate it ... all structures manifest temporal resistance and do so generically by conditioning the context of action. Most often perhaps their conditional influence consists in dividing the population (not necessarily exhaustively) into social groups working for the maintenance versus the change of a given property, because the property itself distributes different vested interests to them ..." (Archer, 2010, p. 239).

With CR as an explanatory framework, Calculus students were under the influence of pre-existing properties and structures produced and reproduced in their past career. The absence of change as observed in this study can be explained by properties and structures continuing to exert constraints after enrollment to the university. Relationships between attitudes, behaviors and academic achievement sustained, only minimally impacted by the interventions. Archer (2010) argues that this can be explained by human reward systems. Intrinsic motivation is driven by internal rewards while extrinsic motivation is driven by external rewards. In a CR perspective, properties and structures manifested themselves in different reward structures. While workload and progression pushed low achievers to practice "survival strategies", high performers could draw on additional resources to the benefit of their vested interests, qualitatively different from their peers. This may be an example of unobservable structures causing observable results. One interpretation would be that reproductive forces inhibited structural elaboration to produce intended changes. This case also demonstrates the significance of time in social change, since structuration processes occur slowly. Change efforts might also have yielded greater impact if measures had been aligned both within and between courses.

\section{Discussion}

Surveys were disseminated electronically once grades were determined. In theory, this may threaten reliability; however, in a comparative study any bias is assumed about equal for both samples and may not affect conclusions. An additional concern is related to the construction of items since a few of them featured multiple questions. This is a valid point; however, items were phrased in order to be recognizable study behaviors by students, and items needed to be identical across the cases.

The plotted curves are similar; however, a closer scrutiny uncovers diverse grade distributions at exams and in surveys. A chi-square goodness of fit test confirmed an overrepresentation of 
the best grades on both occasions, and more so in 2014/2015 compared with 2018/2019. However, minor differences in some desirable attitudes and study behaviors indicate better students in 2018/2019 compared with 2014/2015. Therefore, this overrepresentation does not alter conclusions in any specific direction. Entrance requirements were identical on both occasions, and given the number of students enrolled, we trust cohorts were similar. It would have been of interest to examine potential differences; however, this would have required time and resources beyond the scope of this study.

Findings seem somewhat contradicted by satisfaction studies conducted by the end of the semester indicating improved learning (Langaas et al., 2017; Thaule et al., 2017); however, this may be explained by more tasks requiring imitative rather than creative reasoning (Rønning et al., 2017). The former involves an ability to recall algorithms as opposed to creative reasoning which requires more thinking and problem-solving (Lithner, 2008). The revised course design was initiated with the best of intentions to equip students with learning opportunities; however, with modest success.

To validate findings, conclusions from a previous study in Calculus are included (Sundre, Barry, Gynnild, \& Tangen Ostgard, 2012). The "Achievement Goal Questionnaire" (AGQ) (Elliot \& McGregor, 2001) and the "Attitude Toward Math Instruction" (ATMI) (Tapia \& Marsh, 2002, November) were administered as a pre- and post-test. Motivation and enjoyment decreased, while self-confidence dropped dramatically over the course of the semester, as stated in this quote:

"Over the course of the semester, we observed significant decreases both in "Mastery Approach" (MAP) and "Performance Approach" (PAP), whereas both "Mastery Avoidance" (MAV) and "Work Avoidance" (WAV) increased significantly. The decrease in "Mastery Approach" was the largest change observed. This result is crushing; it suggests that these students significantly decreased in their motivation to take advantage of a learning opportunity. The decrease in Performance Approach suggests that students were significantly less motivated by a desire to look good by earning higher grades. By the time the final examinations had arrived, earning high grades was no longer a realistic outcome for far too many of these students. For many of these students, the goal was now to achieve a grade of " $D$ " or even " $E$," the lowest passing grades. The significant increases observed for "Mastery Avoidance" and "Work Avoidance" were also educationally unwelcome outcomes. The "Mastery Avoidance" increase indicates greater motivation related to the fear of not being able to learn and remember material. The "Work Avoidance" increase suggests a motivation to achieve a learning goal with a minimum of effort. Our data may be interpreted as a change from positive, desirable learning motivations to negative and educationally undesirable learning outcomes." (pp.10-11).

A ten-year follow-up study in 2019 using the same instrument yielded similar results (in review). Our data support the notion that interventions within a stand-alone course may be insufficient to achieve changes in the short term in ways that would be more conducive to desired outcomes. Furthermore, interventions initiated at the semester start occurred in a context not of the university's making:

"Here it appears impossible to follow the methodological individualist and assert that any structural property influential after [semester start] is attributable to contemporary actors (not wanting or not knowing how to change it), because knowledge about it, attitudes towards it, vested interests in retaining it and objective capacities for changing it have already 
been distributed and determined by [the semester start]. Yet without analyzing these we cannot account for when the 'longue durée' is broken, who is primarily responsible for it, or how it is accomplished (by collective policy, social conflict, incremental change etc." (Archer, 2010, p. 240).

Change initiatives may be supported with or without theoretical propositions. In Calculus, theoretical assumptions were kept implicit rather than explicit, making it hard to trace which measures were intended for which problems. Still, Bhaskar (1979) recommends a critical stance to all theories, and "... avoid any commitment to the content of specific theories and recognize the conditional nature of all its results" (p. 5). Theorizing cause and effect might still have been a useful exercise in Calculus.

\section{Summary and Conclusions}

This study confirms strong correlations between High School mathematics and physics grades and achievement in Calculus. Personal characteristics remained strikingly stable from one year to the other, seemingly unimpacted by educational interventions. Compared with their less academically successful peers, high achievers exhibited a different mindset resulting in greater commitment and improved ability to keep pace with workload and progression. Rather than blaming themselves, low achievers attributed own misfortune to others, making the case worse for themselves, while poor grades were attributed to unfair and/or invalid grading procedures. Conversely, the experience of academic success nurtured self-confidence and increased efforts, while absence of such features minimized growth and self-rewarding mechanisms. Defensive strategies may have subverted formative tasks into summative elements in which the search for "correct" solutions took precedence over learning. For a complete overview, important correlations are summarized in Table 3.

\begin{tabular}{|l|l|}
\hline $\begin{array}{l}\text { The better the grades in mathematics and } \\
\text { physics from High School, the better the } \\
\text { grades in Calculus }\end{array}$ & $\begin{array}{l}\text { The poorer the grades in mathematics and } \\
\text { physics from High School, the poorer the } \\
\text { grades in Calculus }\end{array}$ \\
\hline And, the better the grades in Calculus ... & And, the poorer the grades in Calculus ... \\
\hline$\ldots$ the fairer students deemed them to be. & $\begin{array}{l}\ldots \text { the more unfair students deemed them } \\
\text { to be. }\end{array}$ \\
\hline $\begin{array}{l}\ldots \text { the greater the effort and intention to un- } \\
\text { derstand. }\end{array}$ & $\begin{array}{l}\ldots \text { the lesser the effort and intention to un- } \\
\text { derstand. }\end{array}$ \\
\hline $\begin{array}{l}\text { dents. } \\
\text { the more active and hardworking stu- }\end{array}$ & $\begin{array}{l}\ldots \text { the more passive and struggling stu- } \\
\text { dents. }\end{array}$ \\
\hline $\begin{array}{l}\ldots \text { the stronger the perceptions of valid grad- } \\
\text { ing. }\end{array}$ & $\begin{array}{l}\ldots \text { the weaker the perceptions of valid grad- } \\
\text { ing. }\end{array}$ \\
\hline $\begin{array}{l}\ldots \text { the better ability to keep pace with pro- } \\
\text { gression. }\end{array}$ & $\begin{array}{l}\ldots \text { the less ability to keep pace with progres- } \\
\text { sion. }\end{array}$ \\
\hline
\end{tabular}

Table 3: Interrelationships between survey item responses and Calculus grades

The minimal impact of educational interventions is disappointing; however, surprising only in view of simplistic notions of change without consideration of the relationship between 
structure and action. Archer (2010) notes that theoretical developments in social theory have "... tilted either towards structure or towards action" (p. 225) with one often becoming dominant at the expense of the other. In theories of change, views on the role of social institutions have arrived at different conclusions; "institutions as causes of action ... and institutions as embodiments of action" (Archer, 210, p. 229). These mark the divide between determinism and voluntarism; however, the distribution of each may be viewed differently in each case. While it seems apparent that interventions in Calculus appealed to the free will of students, the complexity and mix of properties and structures remained unaddressed.

While we wish to believe in extended opportunities for all, structuring powers are unevenly distributed, as seen in grades and rankings of students. We believe intellectual ability is but one among several driving forces at play in higher education, including workload and progression as particularly influential ones. Due to the nature of structural reproduction, we believe large scale changes in students' behavior is not likely in the short term. Patterns of counterproductive learning behaviors are still of concern since they are likely to reinforce rather than reduce knowledge gaps.

One example of significant change would be poor achievers making the transition from shallow and memory-based learning to deep approaches to learning. Experiencing the joy and satisfaction of in-depth understanding, let's say of a concept, would make any return to past habits less attractive. Transformative learning is documented in studies on threshold concepts (Land, Cousin, Meyer \& Davies, 2005), permitting students a new and previously inaccessible way of thinking about something. Such transitions obviously present important challenges for learning, teaching and course design. If we consider learning in Calculus akin to a journey, a critical point would be the careful attention to problem design as a framework for student engagement. In a CR perspective, we believe a closer attention to, and follow-up of, pre-existing emotional and disciplinary barriers would still be necessary as it is the complex interplay of all properties and structures that make the difference.

\section{Acknowledgement}

Thanks to Professor Frode Rönning, NTNU, for assistance with data collection.

\section{References}

Archer, M. S. (2010). Morphogenesis versus structuration: on combining structure and action. British Journal of Sociology, 61, 225-252. doi:10.1111/j.1468-4446.2009.01245.x

Bhaskar, R. (2015). The possibility of naturalism: a philosophical critique of the contemporary human sciences. In M. Hartwig (Ed.), (4th ed. ed.)

Biggs, J. (1999). Teaching for quality learning at university: what the student does. Buckingham: Open University Press

Bressoud, D. M., Carlson, M., Mesa, V., \& Rasmussen, C. (2013). The calculus student: insights from the Mathematical Association of America national study. International Journal of Mathematical Education in Science and Technology, 44(5), 685-698. Retrieved from https://doi.org/10.1080/0020739X.2013.798874. doi:10.1080/0020739X.2013.798874

Bressoud, D. M., Ghedamsi, I., Martinez-Luaces, V., \& Törner, G. (2016). Teaching and Learning of Calculus. In Teaching and Learning of Calculus (pp. 1-37). Cham: Springer International Publishing 
Cronhjort, M., Filipsson, L., \& Weurlander, M. (2017). Improved engagement and learning in flipped-classroom calculus. Teaching Mathematics and its Applications: An International Journal of the IMA, hrx007-hrx007. Retrieved from http://dx.doi.org/10.1093/teamat/hrx007. doi:10.1093/teamat/hrx007

Elliot, A., \& McGregor, H. (2001). A 2 × 2 achievement goal framework. Journal of Personality and Social Psychology, 80(3), 501-519

Entwistle, N. (1989). Approaches to Studying and Course Perceptions: the case of the disappearing relationship. Studies in Higher Education, 14(2), 155-156. doi:10.1080/03075078912331377466

Fletcher, A. J. (2017). Applying critical realism in qualitative research: methodology meets method. International Journal of Social Research Methodology, 20(2), 181-194. doi:10.1080/13645579.2016.1144401

Frost, G., \& Connolly, M. (2015). The Road Less Travelled? Pathways from Passivity to Agency in Student Learning. Collected Essays on Learning \& Teaching, 8, 47-54. Retrieved from http://search.ebscohost.com/login.aspx?di-

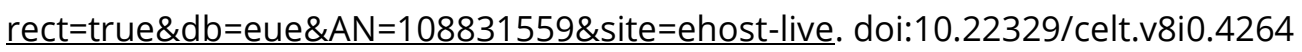

Harrison, L. M., \& Risler, L. (2015). The role consumerism plays in student learning. Active Learning in Higher Education, 16(1), 67-76. Retrieved from http://alh.sagepub.com/content/16/1/67.abstract. doi:10.1177/1469787415573356

Hayward, C. N., Kogan, M., \& Laursen, S. L. (2016). Facilitating Instructor Adoption of InquiryBased Learning in College Mathematics. International Journal of Research in Undergraduate Mathematics Education, 2(1), 59-82. Retrieved from https://doi.org/10.1007/s40753-015-0021-y. doi:10.1007/s40753-015-0021-y

Heid, M. K. (1988). Resequencing Skills and Concepts in Applied Calculus Using the Computer as a Tool. Journal for Research in Mathematics Education, 19(1), 3-25. Retrieved from http://www.jstor.org/stable/749108. doi:10.2307/749108

House, J. D. (1995). The predictive relationship between academic self-concept, achievement expectancies, and grade performance in college calculus. Journal of Social Psychology, 135, 111-112. Retrieved from http://search.ebscohost.com/login.aspx?di-

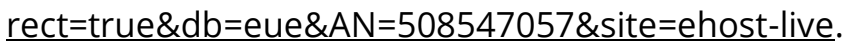
doi:10.1080/00224545.1995.9711411

Jaworski, B., Mali, A., \& Petropoulou, G. (2017). Critical Theorising from Studies of Undergraduate Mathematics Teaching for Students' Meaning Making in Mathematics. International Journal of Research in Undergraduate Mathematics Education, 3(1), 168-197. Retrieved from https://doi.org/10.1007/s40753-016-0044-z. doi:10.1007/s40753-0160044-z

Johnston-Wilder, S., \& Lee, C. (2010). Mathematical Resilience. Mathematics Teaching(218), 38-41. Retrieved from http://search.ebscohost.com/login.aspx?direct $=$ true $\& d b=e u e \& A N=508161464 \&$ site $=$ ehost-live

Langaas, M., Buan, A. B., Skauvold, J., \& Thaule, M. (2017). Læringsressurser i grunnutdanningen i matematikk - kvalitet, tilgjengelighet og differensiering. Læring 
om læring: Proceedings fra Læringsfestivalen 2017(1), 136-143. Retrieved from file:///C:/Users/vidargy/Downloads/271-10-PB\%20(3).pdf

Lithner, J. (2008). A research framework for creative and imitative reasoning. Educational Studies in Mathematics, 67(3), 255-276. Retrieved from http://search.ebscohost.com/login. aspx?direct $=$ true $\& d b=e u e \& A N=508048626 \&$ site $=$ ehost-live. doi:10.1007/s10649-007-9104-2

Land, R., Cousin, G., Meyer, J. H. F., \& Davies, P. (2005). Threshold concepts and troublesome knowledge (3)*: implications for course design and evaluation. In C. Rust (Ed.), Improving Student Learning Diversity and Inclusivity. Oxford: Oxford Centre for Staff and Learning Development.

Pyzdrowski, L. J., Sun, Y., Curtis, R., Miller, D., Winn, G., \& Hensel, R. A. M. (2013). READINESS AND ATTITUDES AS INDICATORS FOR SUCCESS IN COLLEGE CALCULUS. International Journal of Science and Mathematics Education, 11(3), 529-554. Retrieved from https://doi.org/10.1007/s10763-012-9352-1. doi:10.1007/s10763-012-9352-1

Ramsden, P. (1992). Learning to teach in higher education. London: Routledge.

Reinholz, D. L. (2015). Peer-Assisted Reflection: A Design-Based Intervention for Improving Success in Calculus. International Journal of Research in Undergraduate Mathematics Education, 1(2), 234-267. Retrieved from https://doi.org/10.1007/s40753-015-0005-y. doi:10.1007/s40753-015-0005-y

Rønning, F., Buan, A. B., Langaas, M., \& Thaule, M. (2017). Bruk av digitale øvinger i grunnutdanningen i matematikk. Læring om læring: Proceedings fra Læringsfestivalen 2017, 1(1), 113-119. Retrieved from file:///C:/Users/vidargy/Downloads/271-10-PB\%20(3).pdf

Simmons, O., \& Gregory, T. (2003). Grounded Action: Achieving Optimal and Sustainable Change.

Forum: Qualitative Social Research, 4(3). Retrieved from http://nbn-resolving.de/urn:nbn:de:0114-fqs0303271

Snyder, B. R. (1971). The hidden curriculum. New York: Knopf

Sofronas, K. S., DeFranco, T. C., Swaminathan, H., Gorgievski, N., Vinsonhaler, C., Wiseman, B., \& Escolas, S. (2015). A Study of Calculus Instructors' Perceptions of Approximation as a Unifying Thread of the First-Year Calculus. International Journal of Research in Undergraduate Mathematics Education, 1(3), 386-412. Retrieved from https://doi.org/10.1007/s40753-015-0019-5. doi:10.1007/s40753-015-0019-5

Sundre, D., Barry, C., Gynnild, V., \& Tangen Ostgard, E. (2012). Motivation for Achievement and Attitudes toward Mathematics Instruction in a Required Calculus Course at the Norwegian University of Science and Technology. Numeracy, 5(1), 20. Retrieved from http://services.bepress.com/numeracy/

Tapia, M., \& Marsh, G. E. (2002, November). Confirmatory factor analysis of the Attitudes Toward Mathematics Inventory. Paper presented at the Mid-South Educational Research Association, Chattanooga, TN 
Thaule, M., Buan, A. B., Rønning, F., \& Langaas, M. (2017). Alternativ forelesningsstruktur i grunnutdanningen i matematikk. Læring om læring: Proceedings fra Læringsfestivalen 2017, 1(1), 120-128. Retrieved from file:///C:/Users/vidargy/Downloads/271-10-PB\%20(3).pdf

Trigwell, K., Prosser, M., \& Waterhouse, F. (1999). Relations between teachers' approaches to teaching and students' approaches to learning. Higher Education, 37, 57-70

Wheland, E., Konet, R. M., \& Butler, K. (2003). Perceived Inhibitors to Mathematics Success. Journal of Developmental Education, 26(3), 18-27. Retrieved from http://search.ebscohost.com/login.aspx?direct=true $\& \mathrm{db}=e u e \& A N=507822785 \&$ site $=$ ehost-live

White, P., \& Mitchelmore, M. (1996). Conceptual Knowledge in Introductory Calculus. Journal for Research in Mathematics Education, 27(1), 79-95. Retrieved from http://www.jstor.org/stable/749199. doi:10.2307/749199 